Јелена Л. Петковић

Универзитет у Крагујевцу

Филолошко-уметнички факултет

https://doi.org/10.18485/ai_beckovic.2019.ch16

821.163.41.09-1 Бећковић М.

811.163.41'38

\title{
ХОМОГРАФИЈСКЕ И ХОМОФОНИЈСКЕ ФИГУРЕ У КЫИЖЕВНОМ ИЗРАЗУ МАТИЈЕ БЕЋКОВИЋА
}

У раду ће се, на одабраном корпусу, разматрати хомографијске и хомофонијске фигуре у књижевном изразу Матије Бећковића. Показаће се да су хомографијске и хомофонијске фигуре један од битних стилских поступака у књижевном изразу Матије Бећковића. У раду се настоји објаснити и функција ових фигура и њихова улога у поетском тексту, као и њихов утицај на експресивност Бећковићевог књижевног текста.

Кључне речи: хомографијске и хомофонијске фигуре, антанаклаза, полиптотон, парегменон, етимолошка фигура, парономазија.

Дело М. Бећковића карактерише стилистичка раскош и разноврсност, експериментисање у језику и посебне језичке играрије када је често важнији звук од смисла. Истинска поезија остварује се кроз форму, сматра М. Бећковић, без форме поезије не може ни бити. „Бећковићева поезија црпи, као и свака велика поезија, снагу из језичких врела, нарочито архаичних и дијалекатских, углавном заборављених, која он не престаје да открива и истражује." (Зборник радова 2012, 469). Проучаваоци Бећковићевог језика кажу да је „Бећковић (је) мађиони- 
чар преобртања, извлачења неочекиваности, показивања дејстава супротних од очекиваних, понашања супротног од обећаног." (Павловић 1988, XV)

На том трагу у овоме раду настојаћемо да покажемо на који начин стилске фигуре које се могу сврстати у групу хомографијских и хомофонијских фигура утичу на богатство и песничку вредност књижевног израза Матије Бећковића. Фигуре које можемо сврстати у ову групу, дакле у групу хомографијских и хомофонијских фигура, настају понављањем речи или конструкција које имају исту или сличну графијску или изговорну форму, а различито значење, то су фигуре које карактерише „графијска и звуковна подударност или блискост редуплициране језичке јединице и њено различито значење” (Ковачевић 1998, 138), тј. фигуре у којима се понављају језичке јединице са истим или сличним планом израза, а мање или више различитим планом садржаја. Ове фигуре различито се третирају у поетичким и реторичким приручницима. Смештају се унутар фигура дикције (као код Л. Зиме, уп. Зима 1988), унутар фигура елокуције или исказа (као код P. Fontanier, према Женет 2002) или пак унутар фигура речи (као код И. Шкарића, уп. Шкарић 1982). Нема сагласности нити око тога које се фигуре могу објединити називом хомографијске и хомофонијске, а чак постоји изразита неподударност и у дефинисању појединих од ових фигура. Несагласја у дефинисању иду од тога да неки аутори (Зима, нпр., уп. Зима 1988) у ову групу фигура сврставају само оне код којих се редуплицира иста или слична реч, а изостају оне са редупликацијом истих или сличних конструкција (синтагми и клауза), до тога да се у ову групу фигура поред фигура у којима се понављају делови слични на плану израза, убрајају и оне у којима имамо понављање делова истих на плану садржаја (нпр. хомонимија, емфаза и сл). 
За потребе овог радами смо следилидва диференцијална критеријума за уврштење неке фигуре у ову групу, које је истакао проф. М. Ковачевић у својим радовима, а то су „1. редупликација изразно блиске или истовјетне јединице, 2. семантичка неподударност редуплициране јединице." (Ковачевић 1998, 139). На плану израза редуплициране јединице могу бити потпуно и делимично истоветне, док се на плану садржаја може уочити мања или већа разлика у значењу. Следећи ове критеријуме хомографијским и хомофонијским фигурама сматрамо: антанаклазу, полиптотон, емфазу, парегменон, етимолошку фигуру, анаграм, парономазију (и подврсте парономазије апофонију, хомојарктон, хомојотелеутон и хомојоптотон), каламбур и антиметаболу.

У поетском изразу Матије Бећковића на одабраном корпусу ${ }^{1}$ уочили смо највећи број хомографијских и хомофонијских фигура које доприносе стилогености његовог израза и омогућавају да песник каже више и боље од оног што би се из основног контекста могло очекивати, и то антанаклазу, полиптотон, парегменон, етимолошку фигуру, парономазију и антиметаболу, док примера за анаграм и каламбур није било.

Антанаклаза подразумева „графичку и фонолошку подударност и мању или већу семантичку неподударност поновљене речи" (Ковачевић 1998, 141). Ова стилска фигура заснива се на полисемији, хомонимији или хомоформији. Основ стилогености лежи у семантичкој супротстављености којој се противи формална истоветност поновљене речи. Антанаклаза настаје или употребом две речи једнаке на плану израза, а различитог садржаја у истој реченици или већој говорној целини или употребом исте речи у двама различитим значењима или

1 Корпус за ово истраживање чинили су Бећковићеви текстови пописани у одељку ИЗВОРИ на крају рада. 
у двема различитим синтаксичким функцијама унутар једне реченичне или веће целине.

Зима антанаклазу дефинише као подударање „dvije po vanjskom obliku većinom jednake, ali po odnošaju ili značenju različne reči” (Зима 1988, 280). Код античких аутора, она је значила понављање исте речи (у истом облику), али с различитим значењем.

Бећковићеве антанаклазе, као у примерима:

„Погански синови у поганскијем аљинама," (Не дај ce јуначки сине)

„Носи ли он бомбу место главе

Дави ли он речи или њега даве” (Матија Бећковић)

своју поетску снагу црпе из несагласја формалне подударности и семантичке неподударности редуплициране семантички прегнантне језичке јединице, К. Багић сматра да ова фигура „intelektualizira banalne i oživljuje frazeologizirane iskaze” (Багић 2012, 45). Антанаклазом, коју М. Бећковић, у највећем броју примера остварује хомоформима и хомонимима, али и полисемантичним речима, он постиже за читаоца неочекивано појављивање јединице истог плана израза али сасвим различитог плана садржаја. Та неочекиваност на комуникативном плану и лежи у основи стилогене вредности ових јединица.

Полиптотон подразумева понављање исте речи у њеним различитим граматичким облицима, тј., по Шкиљану, понављање исте основе у различитим облицима исте речи (Шкиљан, 2003, 238). У дефинисању ове фигуре готово да нема разилажења међу различитим ауторима, будући да је и у античкој реторици полиптотон описан као понављање исте речи у различитим облицима, посебно падежима. Данас се полиптотон не везује само за именске речи, већ за све променљиве врсте речи (уп. Ковачевић 1998). 
Слично антанаклази, и код ове стилске фигуре М. Бећковић стилематичност постиже понављањем хомокатегоријалне лексеме на блиском одстојању, као у примерима:

„То брдо је порасло у планину

Планину над планинама" (Небом)

„Нема Бога,

А има Божића," (Бишће и Небишће)

То понављање није, међутим, само песнички украс, него се поновљена реч увек јавља у мање или више различитом значењу, и то полиптотонској конструкцији даје стилогену вредност (нпр. планина - врста рељефа одређене надморске висине: планина над планинама планина изузетне лепоте и вредности). Код М. Бећковића, полиптотон се јавља или унутар једног стиха или унутар једне секвенце (најчешће два до три стиха) када он постаје фигура којом се постиже изразита кохезивност израза.

Парегменон подразумева реализацију две или више речи које су обједињене истом коренском морфемом у истом исказу. Шкиљан парегменон дефинише као понављање истог корена у различитим врстама речи (Шкиљан 2003, 223). Тиме се парегменон диференцира и од антанаклазе и од полиптотона, будући да се у њему остварује само редупликација коренске морфеме, тј. само дела редуплициране лексеме. Парегменон је, према К. Багићу (уп. Багић 2012), микроструктурална фигура којом се у истој реченици, стиху или исказу понављају речи истог корена, тј. заједно се појављују најмање две речи које припадају истој лексичкој породици, док се промена облика темељи на афиксима.

Парегменон се може дефинисати „и као реализација два паронима, и као реализација два члана исте творбене 
породице у једноме исказу (или везаноме тексту)" (Ковачевић 1998, 146). Парегменон наглашавајући подударношћу корена исто, заправо тежиште ставља на различито, чији су носиоци афикси. Ова стилска фигура често се остварује у Бећковићевом тексту, као у примерима:

„људи су ме тако цијенили досад,

а тако мислим и посад," (Рече ми један чоек)

„ако је он мене лаго ја полагујем, а што би ме лаго - да излаже колач," (Рече ми један чоек)

„ма немој - мој богоми - ама нека," (Рече ми један чоек)

„Кад смо ође дошли нама мрче,

Послије је само домрцало!" (Шпијун у Ровцима)

„Били кућа на гласу, ко иједна,

Били кућа од завида, ко ниједна," (Двије пјесме)

„А све мање има,

а све више нема!" (Бишће и Небишће)

„Но ме и бише и подбише,

да ми не треба ни Бишће ни Забишће,' (Бишће и Небишће)

Стилематичност парегменонских исказа заснива се на редупликацији основне семантичке компоненте, коренске морфеме, а у исто време и на истицању различитости на плану израза, која се постиже употребом диференцијалних семантичких компоненти које су изражене афиксима. Тако парегменон „варирајући исто и различито, наглашавајући редупликацијом коријенске морфеме исто, инсистира на различитом" (Ковачевић 1998, 147).

Етимолошка фигура је синтаксичко повезивање речи исте основе, порекла, тј. етимологије. Најчешће су 
то зависне синтагме, глаголске синтагме са објектом или прилошком одредбом, али су могуће и именичке синтагме. Код ње се увек наглашава само доминантна семантичка компонента чији је носилац коренска морфема. Етимолошка фигура има врло еуфоничну структуру, као да се у њој „звуци прве ознаке продужавају у поновљеној стварајући тако продужени звучни 'ток', кроз који и захваљујући којем се и остварује стилематичност, а неретко и стилогеност израза" (Ковачевић 1998, 148).

Етимолошку фигуру је на овај начин схватао и Ватрослав Јагић, који је разрадио и њене различите подтипове, разликујући следеће случајеве: субјекат и епитет истог су корена (нпр. колика је ноћиа ноћашна), субјекат и предикат истог су корена (нпр. намера је стариа намерила), предикат и објекат истог су корена (нпр. Дан данише, па и заноћише) и предикат се слаже са инструменталом (нпр. Муч' Тодоре, муком се замук' о). (В. Јагић према Зима 1988, 283-284). Каснији истраживачи уочили су још и слагање предиката и прилошке одредбе (нпр. рано подранила).

Слично парегменону и етимолошку фигуру срећемо често у Бећковићевим стиховима, као у примерима:

„није чоче - јес богоми, - ама велиш ли - велим, све истинску истину, истинит чоек, није од онијег” (Рече ми један чоек)

„Све да ми је неко причо не биг вјерово, тога кукања, у сну се не снило," (Рече ми један чоек)

„имао је и рашта, ноћи ми ноћашње, (Рече ми један чоек)

„Узеће те земља, узела иг узма, (Не дај се јуначки сине) „Нагрдише и косу на главу,

Жалосна жалостила, иња вјера," (Не дај се јуначки сине) 
„Изјела иг дебела шестанска губа, Ударио иг ударац," (Не дај се јуначки сине)

„Кукавица кука зато што ме није родила.” (Доста је било)

„Сва је наша прича допричана." (Лелек мене)

Етимолошка фигура код Бећковића добија своју пуну стилогену вредност захваљујући не само стилематичности конструкције, већ и избору лексема које се у фигури редуплицирају, комбинацији дијалекатске лексике и самосвојних неологизама, специфичним облицима карактеристичним за говор његових Роваца. Код М. Бећковића наилазимо на примере етимолошке фигуре која се заснива на синтагматском односу конгруенције (нпр. истинска истина, ноћи ми ноћашғе), затим на односу управљања (рекције), као у примерима узела иг узма, ударио иг удараи, или на односу придруживања (нпр. муком замукао).

Парономазија је повезивање речи гласовно сличних, али етимолошки различитих да би се истакла нека подударност или супротност њиховог значења (уп. Ковачевић 1998). Постоји више врста парономазије: апофонија је врста парономазије у којој се разлика између две речи темељи на минималној фонолошкој разлици, хомојарктон је гласовно подударање на почетку речи, хомојотелеутон је парономазија која се темељи на подударању завршетака речи, док је хомојоптотон понављање граматичких наставака две или више речи.

Сматра се да је парономазија „боља што је ближа 'истозвучности', односно што је диференцијални део две лексеме мањи" (Ковачевић 1998, 150). У Бећковићевом поетском изразу срећемо примере апофоније: 
„Нијесам те родила да те они мерају, Да ти младос у нерадос проди." (Не дај се јуначки сине)

„Иза великога полома, остали ко иза грома,” (Не дај се јуначки сине)

\section{или хомојоптотона}

„Не дај се тањевини, покарама, вегама, постреварама,... Не дај се фуњарама, пошушњарама, постреварама,... Не дај се ичмилети, писмилети, свакој милети." (Не дај се јуначки сине)

Сви уочени примери парономазије, код М. Бећковића, имају циљ „стварања привида једнакозвучја две различите лексеме који ће се онда пренети и на изреку у целини" (Ковачевић 1998, 151). Управо на том привиду хомографичности и хомофоничности, парономазија и темељи своју стилематичност и зато је ту у првом плану лепота форме, а она је тим боља што обједињује више различитих, а случајно фонолошки и графемски блиских јединица. Тиме форма постаје врло упечатљива јер ствара „тзв. продужено звучање” (Радуловић 2012). Сасвим је очигледно да ови хомографијски и хомофонијски стихови код М. Бећковића блискозвучношћу семантички неподударних редуплицираних јединица увек стварају готово идеалан спој мисли и израза, отуда се они и „доимају као непоновљиви и случајно ухваћени спој бисерне мисли и још бисерније форме” (Радуловић 2012) Ако прихватимо да је парономазија „vezana za intelektualni, cizelirani prozni izraz, čije je glavno oružje duhovitost.” (Речник књижевних термина 1986, 528), онда то парономазије М. Бећковића сврстава у врхунске.

М. Бећковић парономазију често користи као структурну компоненту својих стихова прожимајући њоме, 
као у песми Не дај се јуначки сине, песму од почетка до краја, те читамо и

„Кад салете мочугама, тојагама, љускама, ленгама, јаргама, Врљикама, ћепаницама, приткама, волујскијем жилама, Држалицама, замлатицама, брстинама, јастигачама, Дрвеницама, матинама, лисникама, окресинама...” (Не дај се јуначки сине)

Примера коришћења антиметаболе, која настаје понављањем истих чланова конструкције у обрнутом распореду и обрнутој синтаксичкој функцији, у испитиваном корпусу није било много, но и у тим малобројним примерима, показује се да и ова стилска фигура у изразу М. Бећковића има изузетну експресивну вредност, као у примеру „Умирати могу само живи, / А живјети могу само мртви!" (Унук Алексе Маринкова плаче над Црном Гором), док примера за анаграм и каламбур није било.

Проведена анализа употребе хомографијских и хомофонијских фигура у књижевном изразу М. Бећковића показала је још једном сву Бећковићеву маестралност у коришћењу језичких потенцијала. На моменте се, током читања, може учинити да је Бећковићев текст презасићен понављањима сваке врсте и делом редундантан, да се уочавају правилности у понављању које се лако могу предвидети, но, већ на други поглед сасвим је јасно да у Бећковићевом исказу нема ама баш ничега сувишног, структурна понављања, као и структурна варирања нису само композицијски поступак, већ представљају смисаони поступак надградње основног тока мисли, додатка нове идеје основној, што води смисаоном богаћењу текста и додатном истицању основне идеје у први план. 


\section{ИЗВОРИ}

Матија Бећковић, Тако је говорио Матија, Београд: Просвета, 1965.

Матија Бећковић, Поеме (Рече ми један чоек, Међа Вука Манитога, Леле и куку) Београд: Српска књижевна задруга, 1983. Матија Бећковић, Кажа, Београд: Српска књижевна задруга, 1988.

Матија Бећковић, Црногорске поеме, Београд: АСТИМБО, 2002.

\section{ЛИТЕРАТУРА}

Багић 2012: K. Bagić, Rječnik stilskih figura, Zagreb: Školska knjiga, dostupno na http://inet1.ffst.hr/_download/repository/ Kresimir_Bagic_-_Rjecnik_stilskih_figura.pdf.

Женет 2002: Ž. Ženet, Figure V, Novi Sad: Svetovi.

Зборник радова 2012: О песмама, поемама и поетиии Матије Бећковића, уредници Јован Делић, Драган Хамовић, Београд - Требиње: Институт за књижевност и уметност, Учитељски факултет Универзитета у Београду, Дучићеве вечери поезије, Требиње.

Зима 1988: L. Zima, Figure u našem narodnom pjesništvu, Zagreb: Globus.

Ковачевић 1998: М. Ковачевић, Хомографијске и хомофонијске фигуре у афоризму, Стилске фигуре и кюижевни текст, Београд, 137-156.

Ковачевић 1998': М. Ковачевић, Стилске фигуре и књижевни текст, Београд: Требник.

Ковачевић 2011: М. Ковачевић, Мимолошки језичко-стилски поступци у Вуковој азбуци Душана Радовића, Стилска значень и зрачень, Ниш, 117-137.

Милановић 2016: А. Милановић, Иза језичке игре у Бећковићевој поеми Ћераћемо се још, Реч под окриљем политике, Краљево, 2016, 119-141.

Павловић 1988: М. Павловић, О новој поеми Матије Бећковића, предговор књизи Кажа, Српска књижевна задруга, Београд, VII-XIX. 
Радуловић 2012: Z. Radulović, Stilske karakteristike u djelima Stefana Mitrova Ljubiše i Marka Miljanova Popovića, доступно на http://docplayer.net/21679852-Stilske-karakteristike-u-djelimastefana-mitrova-ljubise-i-marka-miljanova-popovica.html

Речник књижевних термина 1986: Rečnik književnih termina, Beograd: Nolit.

Шкарић 1982: I. Škarić, U potrazi za izgubljenim govorom, Zagreb: Školska knjiga.

Шкиљан 1986: D. Škiljan, Antičke figure i tropi i suvremena lingvistika, Latina et Graeca, broj 27, Zagreb, 5-22.

Шкиљан 2003: D. Škiljan, Leksikon antičkih termina, Zagreb: Antibarbarus - Latin et Graeca.

Jelena L. Petković

\section{HOMOGRAPHIC AND HOMOPHONIC FIGURES IN LITERARY EXPRESSION OF MATIJA BECKOVIC}

In our paper we have examined, on selected corpus, homographic and homophonic figures in literary expression of Matija Beckovic. We showed that both homographic and homophonic figures are one of the important stylistic methods used in literary expression of Matija Beckovic. Also, we explained their function and role in poetic text as well as their impact on Beckovic's literary text expression.

Key words: homographic and homophonic figures, antanaclase, polyptoton, paregmenon, etymological figure, paronomasia. 